\title{
回想分析を用いた旧街道型細街路の街路イメージの比較* 土地利用状況の異なる旧街道型細街路を事例として
}

Comparison of the street image in the old high streets by using analysis of memories *

亀谷一洋**・山中英生 $* * *$. 三宅正弘**** By Kazuhiro KAMETANI** - Hideo YAMANAKA*** - Masahiro MIYAKE****

\section{1.はじめに}

現在のまちづくりにおいては、ハード、ソフト にかかわらず、対象地域で生活している住民の意見 を聞くことは重要な意味合いを持っている。今日、 住民の意見聴取の方法としてはアンケート調査が一 般に用いられているが、表層的意見の収集にとどま ることが多い。一方、ワークショップではグループ ダイナミックスを用いた効果的な意見収集が試みら れているがその体系的分析方法は確立していない。

本研究では、街路計画での沿線住民の参加型手 法として回想分析を用いて、街路設計に活かす情報 を収集するという質的調查の開発とその有効性を明 らかにすることを目的としている。具体的には、旧 街道型細街路の再生計画を時間軸という概念を用い た回想分析手法を用い、インタビュー形式のヒアリ ングにより、なくなってしまった過去のイメージを 記録し、オーラルヒストリーを分析することから旧 街道型細街路のイメージを抽出する。先行研究 ${ }^{1)}$ では、旧街道の商店街においてこの手法で街路イメ ージの抽出をおこなった。本研究ではこの手法を住 居系旧街道型細街路に適用し、有効性を検証する。 また、2 地区の回想分析結果を比較分析することに より、旧街道型細街路の持つ街路特性を明らかにす る。

街路のイメージに関する研究は、安藤ら ${ }^{2)}$ が、 さまざまな街路を事例に、そのコンピューター・グ ラフィックスを用いてのイメージの定量化をおこな っている。平野ら ${ }^{3)}$ は、繁華街での街路イメージ *キーワード：地区交通計画、市民参加、イメージ分析 **正員、工博、徳島市役所開発部公園緑地課 （徳島市幸町 2 丁目 5 番地、 TEL088-621-5295、FAX088-621-5273)

***正員、工博、徳島大学工学部建設工学科 (徳島市南常三島町 2 丁目 1 番地)

****正員、工博 同上
の類型を明らかにしているが、旧道再生に関する研 究事例は少ない。

本研究では、住居系旧街道型細街路として徳島県 徳島市上佐古通りと商店街系旧街道型細街路として 徳島県羽ノ浦町商店街を事例として、回想分析法を 用いて、旧街道型細街路利用者が持つ旧街道型細街 路の街路イメージの分析とその比較をおこなう。

\section{2. 回想分析}

\section{（1）個別ヒアリング}

今回、沿線住民に対して個別インタビューによ るヒアリングを行い、回想分析をおこなった。この 手法は、幅広い人達の意見を聞くことはできないが、 被験者の意見を時間をかけて聞き取ることができ、 詳細について追問することができる手法である。回 想分析とは、今までの日々の生活において、前の道 路で思い出す楽しかった（よい）イメージ、わるい イメージを被験者 1 人 1 人に個別インタビューし、 その要素と連関を分析する方法で、臨床心理で用い られる重要事項分析の手法を道のイメージ抽出に改 良したものである。インタビューの手順を以下に記 す。

1）被験者に「家の前の道で思い出す、よいイメー ジ、わるいイメージの出来事や体験したことを何 でも自由にお話ください。」と問いかける。そし て発言内容の時代や被験者の気持ちを確認するた め、「それはいつの頃の話ですか。」とか「その ときあなたはどう思いましたか。」などの質問を はさみながら、その時の道路状況を具体的に話さ せ、イメージの年代を確認する。

2）引き続き、「他に家の前の道で思い出す、よ いイメージ、わるいイメージの出来事や体験し たことはありませんか。」と問いかけ、そのイ 
メージの年代を確認する。被験者に自由に話を してもらうことを目的とし、インタビューアは、 聞き手に徹して、時代や道路状況を確認する問 いかけのみを行うように注意し、この問いかけ を繰り返し行う。

\section{（2）イメージラダーでの分析}

次に発言項目の内容を分解し、D. N. Hinkel によ

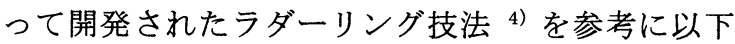
の方法でイメージラダーを作成した。

たとえば、「家の前の道路で思い出すよいイメ ージ、わるいイメージの出来事や体験を何でも自由 にお話ください。」との問いかけに対して、たとえ ば、「夏祭りに人がたくさん来てくれて楽しかっ た。」という回答があった場合は、まず現場で、

「それはいつ頃の話ですか。」とその年代を確認す る。

次に発言を「夏祭り」、「人がたくさん来てく れた」、「楽しかった」に分ける。

そして全体の概念である「夏祭り」を上位項 目に、具体内容としての「人がたくさん来てく れた」を下位項目として配置し図上では矢印で 示す。そして、「楽しかった」はよいイメージ に分類する。図では、わるいイメージのみ $\boldsymbol{\Delta}$ 印 で表している。これを時間軸上に配置する。こ の作業を、繰り返し行うという手法である。

\section{3. 回想分析からみる上佐古通りの街路イメー ジの抽出}

（1）上佐古通りの現況

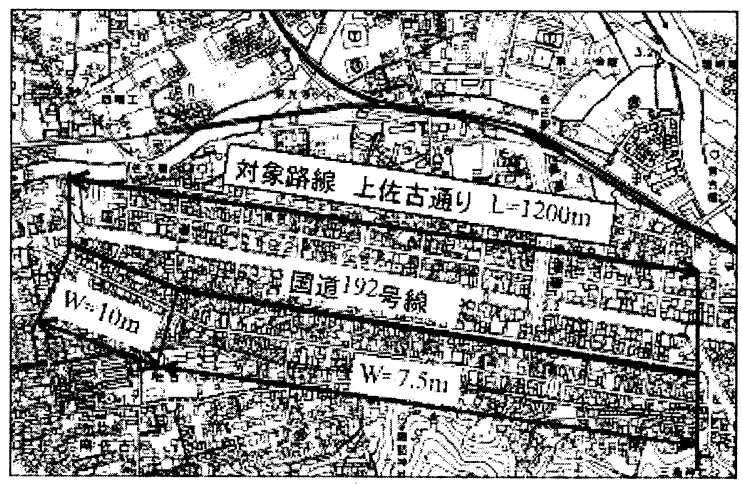

図一 1 上佐古通り対象区域図
調査対象は徳島市中心より西 $2 \mathrm{~km}$ に位置する 佐古地区にある。国道 192 号線の 1 つ南側にあ る旧街道型細街路である。江戸時代から街並み は格子状に構成されていたが、昭和 28 年に国 道が整備され現在の形となっている。

上佐古通りは、延長約 $1,250 \mathrm{~m}$ 、幅員 $7.5 \sim$ $10.0 \mathrm{~m}$ の徳島駅方面への一方通行道路である。 沿線は住宅地で住居は 106 棟、商店は 69 棟で ある。平日 12 時間交通量は約 1,400 台である。

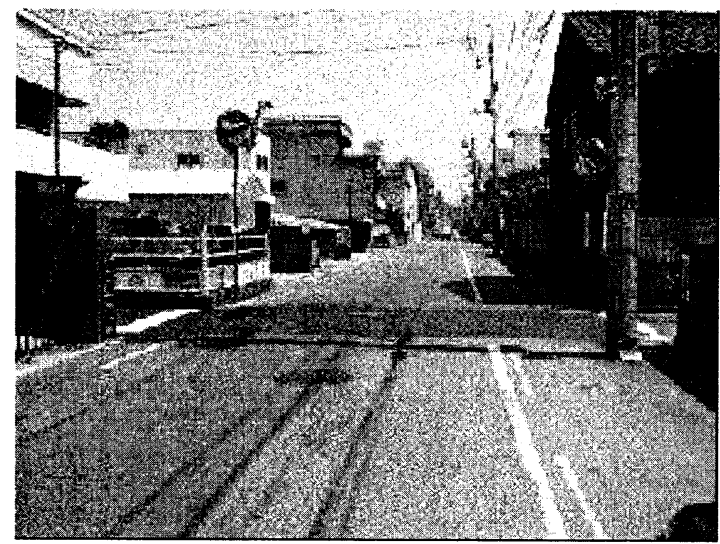

写真一 1 上佐古通り現況

（2）実験方法

上佐古通り沿線住民に対して、インタビュー形式 によるヒアリングを行い、上佐古通りに関するイメ ージ把握を試みた。対象被験者は、60〜80歳代の男 性3名、女性3名である。インタビューは、平成15年 8月〜11月にかけて行い、状況については、テープ に録音している。インタビュー1人あたりの所要時 間は、特に決めていなかったが、実際には、20分か ら1時間程度であった。

（3）回想分析による上佐古通りのイメージ抽出 図- 2 は回想分析の結果である。 これより以下のことがわかる。

(1) 上佐古通り沿線の被験者たちは、少年、少女 期に夜店や屋台などが出ていたことを、覚えて いて、それをよいイメージとして持っている。

(2) 被験者の年代がよく似ていることもあるが、 昭和初期から昭和 20 年代まで道路上で多くの 遊びを自分たちが体験していたことがわかる。

(3) 終戦直後は、戦後の苦しい生活の状況や仕事 関連の風景を街路イメージとして持っている。

琴の音や駅の灯りなど、物質社会とは違った 


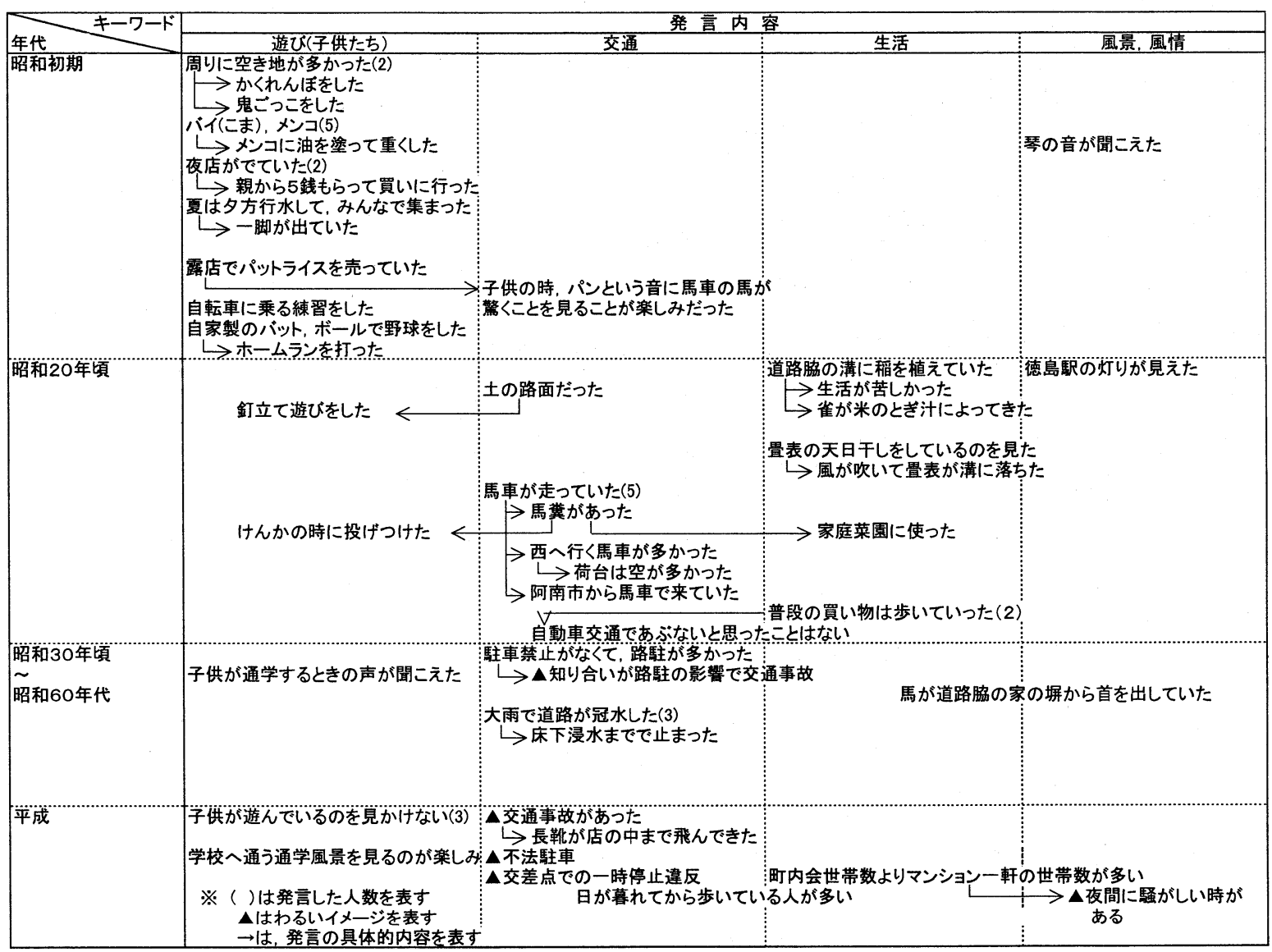

図一2上佐古通りイメージラダー図

時代の風情が街路上に醇し出されていた可能性 がある。人や物にはない街路の䨌囲気ともいえ るものが戦後しばらくはあったのではないだろ うか。しかし最近では、これが騒音になってい る。

(5) 子供が少なくなって街路上で子供を見かける ことはほとんどなく、そのことが街路の䨌囲気 にも影響が出ていることがいえる。

被験者の方が雑談で話していたが、その人の町内 会は、子供会は 3 人だけで、 79 歳以上の敬老会の 案内を出すのは 16 人となっている。少子高龄化の 影響は、沿道利用者が感じる旧街道型細街路の街路 イメージにも大きな変化を与えている。

\section{4. 旧街道型商店街との街路イメージの比較}

\section{（1）羽ノ浦町商店街}

次に回想分析を用いた商業系旧街道型細街路に おける街路再生コンセプトの抽出事例 ${ }^{1)}$ との比較
分析を行った。

羽ノ浦町は、徳島県の南部に位置し、県都徳島 市から南に約 $15 \mathrm{~km}$ の距離にある、面積 $8.9 \mathrm{~km}^{2} 、$ 人口約 12,000 人の町である。

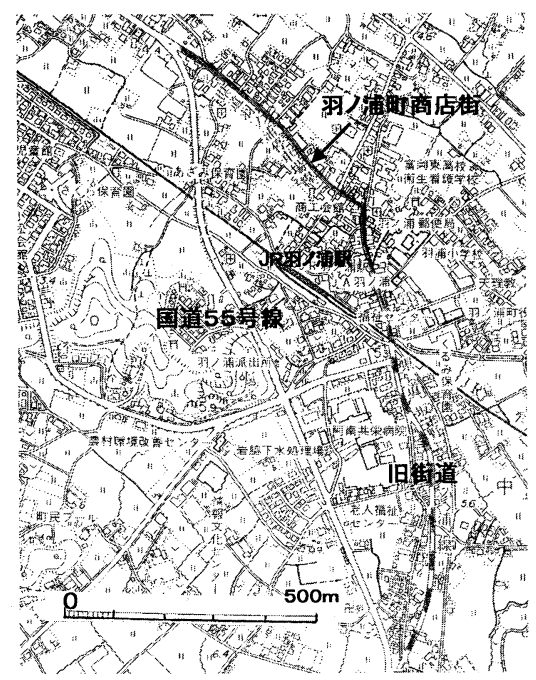

図－3 羽ノ浦町商店街対象区域図 


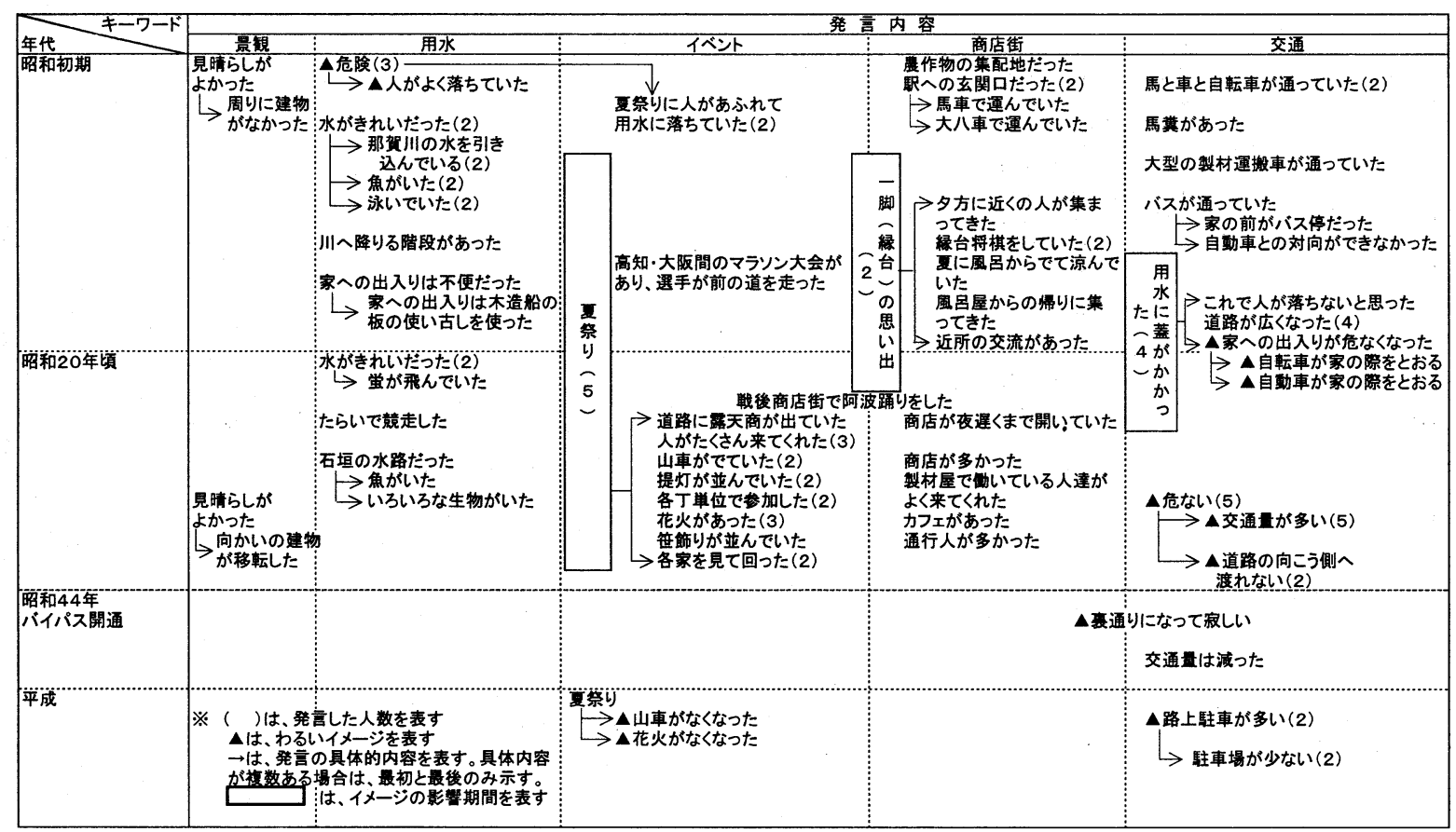

\section{図一4 羽ノ浦町商店街イメージラダー図}

羽ノ浦町商店街は、羽ノ浦町の中心部に位置す る延長約 $800 \mathrm{~m}$ 、幅員6 10m の旧国道沿いに発展し た旧街道商店街で、古くは土佐街道として徳島県と 高知県を結ぶ幹線街道上にあった。昭和初期には、 一部道路の両側に幅 $2 \sim 3 \mathrm{~m}$ の用水が流れていたが、 昭和7年頃から順次、蓋がかけられ、昭和 27 年頃に 商店街部分は全線蓋がかけられ、現在の道路断面形 状が形成された。さらに、昭和 44 年に商店街を迂回 する国道バイパスが完成し、旧街道は県道となる。 現在、商店数は 43 店舗、民家は 37 軒、その他 3 軒と なっている。被験者は、住民 8 名を対象で、50代か ら80代の男性 7 名、女性1名である。ヒアリングの 詳細については参考文献 ${ }^{1)}$ に詳説しているため、こ こでは図一 4 に結果のみを表示する。

\section{（2）イメージラダー図の比較}

それぞれの路線でインタビューに応じてくれた被 験者の年齢層が似通っていることに着目し、2つの イメージラダー図を比較分析する。

この 2 つイメージラダー図を年代別に重ね合わ せて、2 つのイメージラダー図に共通にあるイメー ジと独自にあるイメージに分類した。また、上佐古 通り、羽ノ浦町商店街それぞれの街路でしか発言さ れていない内容であっても、被験者の内容が明らか
に $2 つ の$ 街路に共通となるイメージについては言葉 が異なっても「ほぼ同一の情景を指し示す」発言とし て、中間イメージの欄に書き込んだ(昭和 30 年頃の 路上駐車など)。その結果を表一 1 示す。

（3）街路イメージの共通性と独自性

表一 1 より、沿線住民が持っている旧街道型細 街路の街路イメージは、共通性と地域の独自性のイ メージがあることがわかる。

街路イメージの共通性は社会の流れに応じて、 人々の生活習慣や共通の文化から生まれてきた行動 形式に伴う街路イメージで、ここでは、まだ自動車 の少なかった時代に夕方になると近所の人たちや、 行水を終えた子供達が溜まり場となっている家の前 の一脚を囲んで一日の出来事やご近所のことを話し 合ったり、遊んだりしている情景がこれにあたる。

旧街道型細街路の再生を計画する際には、この ような沿線で生活をしている人達が溜れる空間を設 けることが設計コンセプトの 1 つになってくるので はないだろうか。限られた街路空間にこのような溜 まり場を再現するには、さらなる通過交通量の削減 や、速度規制の検討も重要な検討課題となってくる と考えられる。

また、このような情景はさらに歴史性、幹線性 
表ー1 2つの旧街道型細街路の街路イメージの共通性と独自性

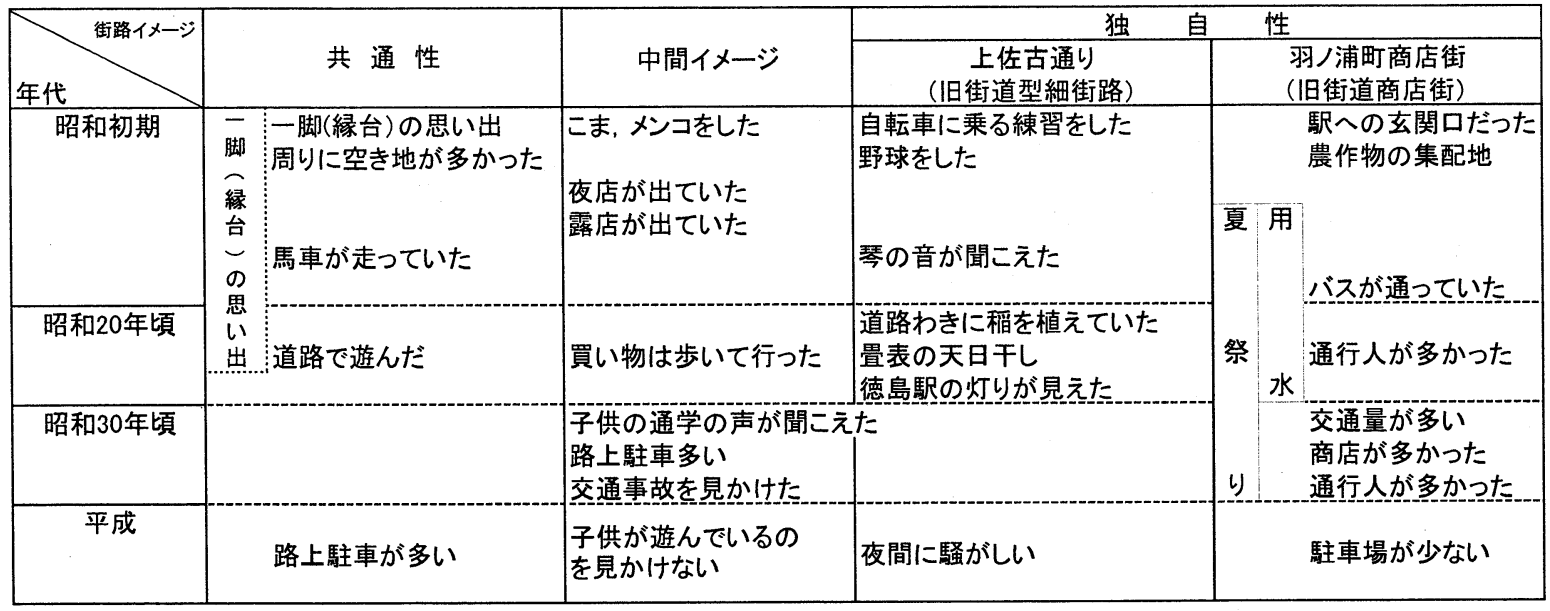

を持っている旧街道型細街路独自のものと、その時 代にどこの街路や路地裏でも見られた情景とに分類 することも可能である。荷物を積んだ馬車に関する イメージなどは当時幹線機能を持っていた旧街道型 細街路ならではの街路イメージといえる。また、今 日では、路上駐車や交通事故の問題など、交通安全 に対する発言が多かったことも両街道に共通してい る。

2 地区の街路イメージを比較すると、住居系の旧 街道型細街路と商業系の旧街道商店街では被験者 が持つ街路イメージに違いがあることがわかる。

住居系の旧街道型細街路である上佐古通りは、自 転車に乗る練習をしたり、野球をして遊んだりとい う街路で場所をとる遊びをしたイメージを持ってい る。また、夜は静かであったのか、琴の音が聞こえ たり、中心市街地の徳島駅の灯りが見えたという風 流なイメージも持ち合わせている。

一方、旧街道商店街の羽ノ浦町商店街では、街路 に平行に流れていた用水路で遊んだイメージが強く 残っていて、子供達にとっては日常生活の中で、用 水と街路は一体となった空間として認識、活用され ていた。また、古くからの商店街らしく、夏祭りの 思い出や、早くからバスが通っていたイメージは商 店街の活気があった時の時期とも重なって、被験者 の持つ街路イメージを鮮明にしているといえる。

\section{5. 結 論}

回想分析法を用いて沿線住民にヒアリングを
行い、その結果をラダー構造で表現することに より、沿線住民の持つ旧街道型細街路に対する 意識を図上に表すことができた。また、土地利 用状況の異なる旧街道型細街路においては、沿 線住民が持っている街路イメージには時代の変 遷による旧街道筋ならではの共通性と、土地利 用状況や地域文化のよって育まれてきた独自性 があることを図上で表現できた。旧街道型細街 路の再生にはこれらの独自性を街路ユーザーに 想起、認識させる施策が必要と考えられる。

この回想分析は、旧街道型細街路など、歷史 性を持つ街路再生について、沿線住民という 「街路ユーザー」の視点を、設計者やまちづく りプランナーなどの視点と融合するための一手 法としての有効であると考えられる。

今後は、旧街道型細街路の独自性をさらに分 析するとともに、街路ユーザーが街路に対して 持っている潜在的イメージを街路計画に反映す るための参加型デザインプロセスへの応用につ いて進めていきたいと考えている。

\section{参考文献}

1）刍谷一洋, 山中英生, 三宅正弘：回想分析を用い た旧街道商店街の街路イメージの分析，土木計画 学研究・論文集 Vol.20no. 2, pp. 433-440, 2003 年 9 月

2）安藤直見，八木幸二，茶谷正洋 : 都市中心部にお ける街路空間のイメージ分布, 日本建築学会計画 系論文集第 497 号, pp. 155-162，1997 年

3）平野勝也，資延宏紀：街路イメージ類型を用いた 繁華街構成分析, 土木計画学研究・論文集, No. 17, pp. 533-540, 2000 年

4）讃井純一郎，乾正雄：レパートリー・グリッド発 


\section{回想分析を用いた旧街道型細街路の街路イメージの比較}

本論文では、旧道の再生問題について、回想分析を用いて土地利用状況の異なる旧街道型細街路 における沿線住民が持っている街路イメージを分析した。その結果、歴史性を持つ旧街道型細街路 沿線住民は、旧街道沿線という歴史性による街路イメージの共通性と土地利用状況や地域文化の違 いによる独自性を持っていることがわかった。これより、旧街道型細街路の再生には、沿線住民が 街路に対して持っている潜在的な街路イメージを想起させることにより、街路計画を作成する有効 性を示した。

Comparison of the street image in old high streets by using analysis of memories *

By Kazuhiro KAMETANI** - Hideo YAMANAKA***. - Masahiro MIYAKE****

In this paper, streets image was analyzed by using analysis of memories in the old high streets. Two types of streets which have different land use were compared. Consequently, residents of along the streets have similarity and peculiarity about the streets image. Validity of using analysis of memories on the planning of old high streets is found as results of this study. 